\title{
HISTORICAL TEPHRA-STRATIGRAPHY OF THE COSIGÜINA VOLCANO (WESTERN NICARAGUA)
}

\author{
Petr Hradecký* \& Vladislav Rapprich \\ Czech Geological Survey (CGS), Klárov 3, 11821 Prague, Czech Republic \\ * Autor para contacto: petr.hradecky@geology.cz
}

(Recibido 11/04/07; aceptado 03/05/08)

\begin{abstract}
New detailed geological field studies and ${ }^{14} \mathrm{C}$ dating of the Cosigüina Volcano (westernmost Nicaragua) allow to reconstruct a geological map of the volcano and to establish a recent stratigraphy, including three historical eruptions. Five major sequences are represented. I: pyroclastic flows around $1500 \mathrm{AD}$, II: pyroclastic flows, scoria and pumice flows and surges, III: pyroclastic deposits related to a litoral crater, IV: pyroclastic flows related to 1709 AD eruption, and finally, V: pyroclastic deposits corresponding to the cataclysmic $1835 \mathrm{AD}$ phreatic, phreatomagmatic and subplinian eruption, which seems to be relatively small-scale in comparison with the preceding historical eruptions. The pulsating geochemical character of the pyroclastic rocks in the last five centuries has been documented. The beginning of every eruption is marked by increasing contents of silica and Zr. Based on that, regardless of present-day volcanic repose, the entire Cosigüina Peninsula should be considered as a very hazardous volcanic area.
\end{abstract}

Key words: Cosigüina volcano, tephra-stratigraphy, Nicaragua, Fonseca Gulf, ${ }^{14} \mathrm{C}$ dating.

RESUMEN: Nuevos estudios de campo detallados realizados en la zona del volcán Cosigüina (occidente de Nicaragua), junto con dataciones ${ }^{14} \mathrm{C}$, permitieron la reconstrucción de un mapa geológico y de la estratigrafía reciente de los depósitos piroclásticos, incluyendo tres erupciones históricas. Se encontraron cinco secuencias mayores. I: flujos piroclásticos cerca del año 1500 dC; II: flujos piroclásticos, flujos de escoria y pómez y oledas piroclásticas; III: depósitos piroclásticos relacionados con un cráter litoral; IV: flujos piroclásticos relacionados con la erupción del año 1709 dC, y finalmente, V: los depósitos piroclásticos correspondientes a la erupción cataclísmica del año 1835 dC, de carácter freático, freatomagmático y subpliniano, que parece ser de pequeña escala en comparación con las previas erupciones. Los productos analizados de las erupciones de los últimos cinco siglos revelan el carácter pulsante del contenido de $\mathrm{SiO} 2$ y Zr. A pesar de que el volcán se encuentra en estado de calma por más de 170 años, por su registro de erupciones violentas, así como por dicha variación química del magma, la península de Cosigüina puede considerarse como un área de alto peligro volcánico.

Palabras claves: Volcán Cosigüina, tefraestratigrafía, Nicaragua, Golfo de Fonseca, datación ${ }^{14} \mathrm{C}$.

HRADECKÝ, P. \& RAPPRICH, V., 2008: Historical tephra-stratigraphy of the Cosigüina volcano (Western Nicaragua). - Rev. Geol. Amér. Central, 38: 65-79. 


\section{INTRODUCTION}

Cosigüina Volcano is a broad volcanic shield lying on the westernmost limits of the Nicaraguan territory (e.g. Weyl, 1980), being part of the volcanic belt genetically associated with subduction of the Cocos plate beneath the Caribbean plate (Mann, 1995 and references therein). It is best known by its 1835 eruption (Mc Birney \& Williams, 1965; Williams, 1952; Self et al., 1989). The 700-m-deep crater has been formed by several violent explosive events. The presentday volcano rests on remnants of an older basaltic-andesite stratovolcano (Pre-Cosigüina stage), presumably of Pleistocene age, similarly to the eroded San Juan volcano located nearby.

Cosigüina Volcano is located at the Nicaraguan side of the Fonseca Gulf. The origin of this gulf, separating the Nicaraguan and Salvadorian segments of the Central American volcanic belt, is by the intersection of three first-order tectonic structures (Fig. 1). Such complicated tectonic setting is the result of the oblique subduction on the Central American trench. Steep angle of subduction is responsible for the extension and formation of the Central Graben (Salvadorian C.G. and Nicaraguan Depression). The oblique convergence of lithospheric plate leads to strike-slip of the Chortis block to the east along the Polochic-Motagua-Jocotán fault system (Burkart \& Self, 1985). Heterogeneous rates of this eastward motion rebound in the formation of the north-south trending grabens and the northeast-southwest trending Guayape left-lateral strike-slip fault (Finch \& Ritchie, 1991). In the area of Fonseca Gulf, the Guayape fault breaks the Central Graben and displaces the Salvadorian part to the southwest from the Nicaraguan segment. The Guayape fault is probably also responsible for the northwest limit of the Cosiguiina peninsula.

\section{Previous research}

Recent publications focus predominantly on the 1835 eruption of Cosiguiina (Fig. 2) and its impact on society and atmosphere. Various authors have documented the products of the
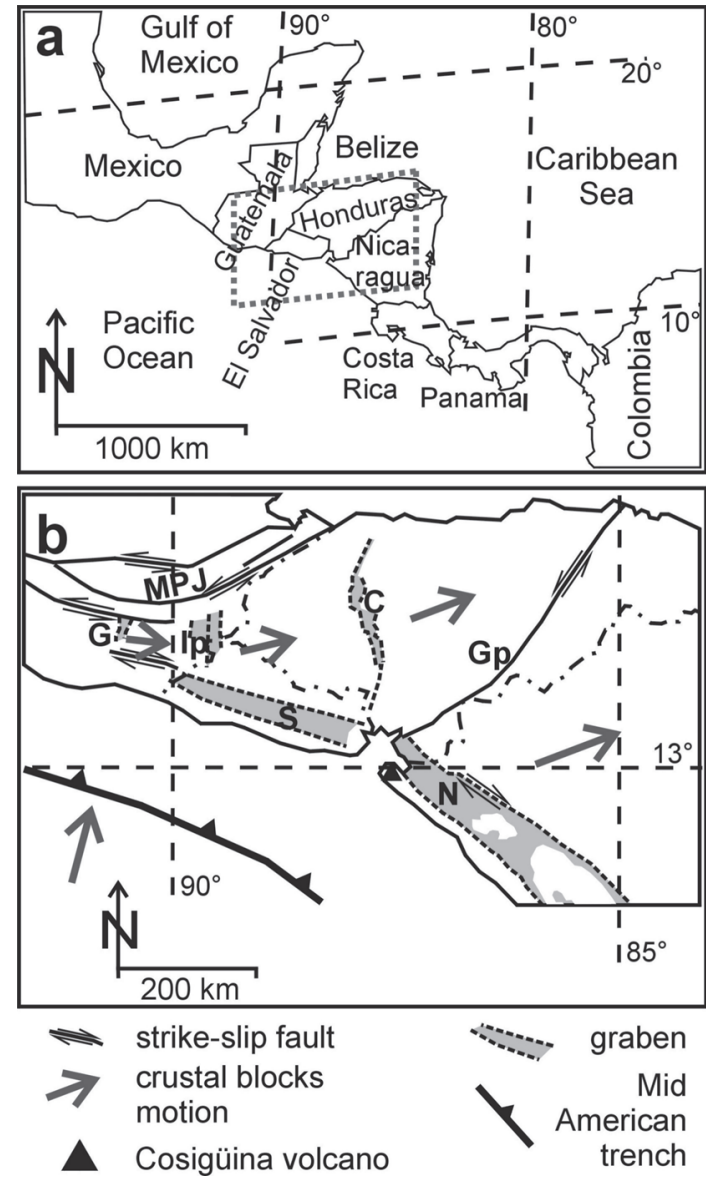

Fig. 1: Location of the study area and relations to the principal tectonic structures: C - Comayagua Graben, $\mathrm{G}$ - Guatemala City Graben, Gp - Guayape fault system, Ip - Ipala Graben, MPJ-Motagua-Polochic-Jocotán fault system, N-Nicaraguan Depression, S - Salvadorian Central Graben (simplified after Burkart \& Self, 1985).

youngest eruptions from the southern and eastern slopes of the edifice (e.g. Self et al., 1989; Scott et al., 2006). The previous evolution of this volcano was in contrast studied scarcely and if so, only briefly. Williams (1952) reported more than 30 lava flows exposed in the vertical crater walls with separating tuffs layers. Close to the hacienda Los Pozos on the southern outskirts of the volcano, he described basaltic-andesite lavas with plg $>$ cpx $>$ op $x>$ ol $>$ mt, with some olivine xenoliths (currently not confirmed). Similar rocks are 

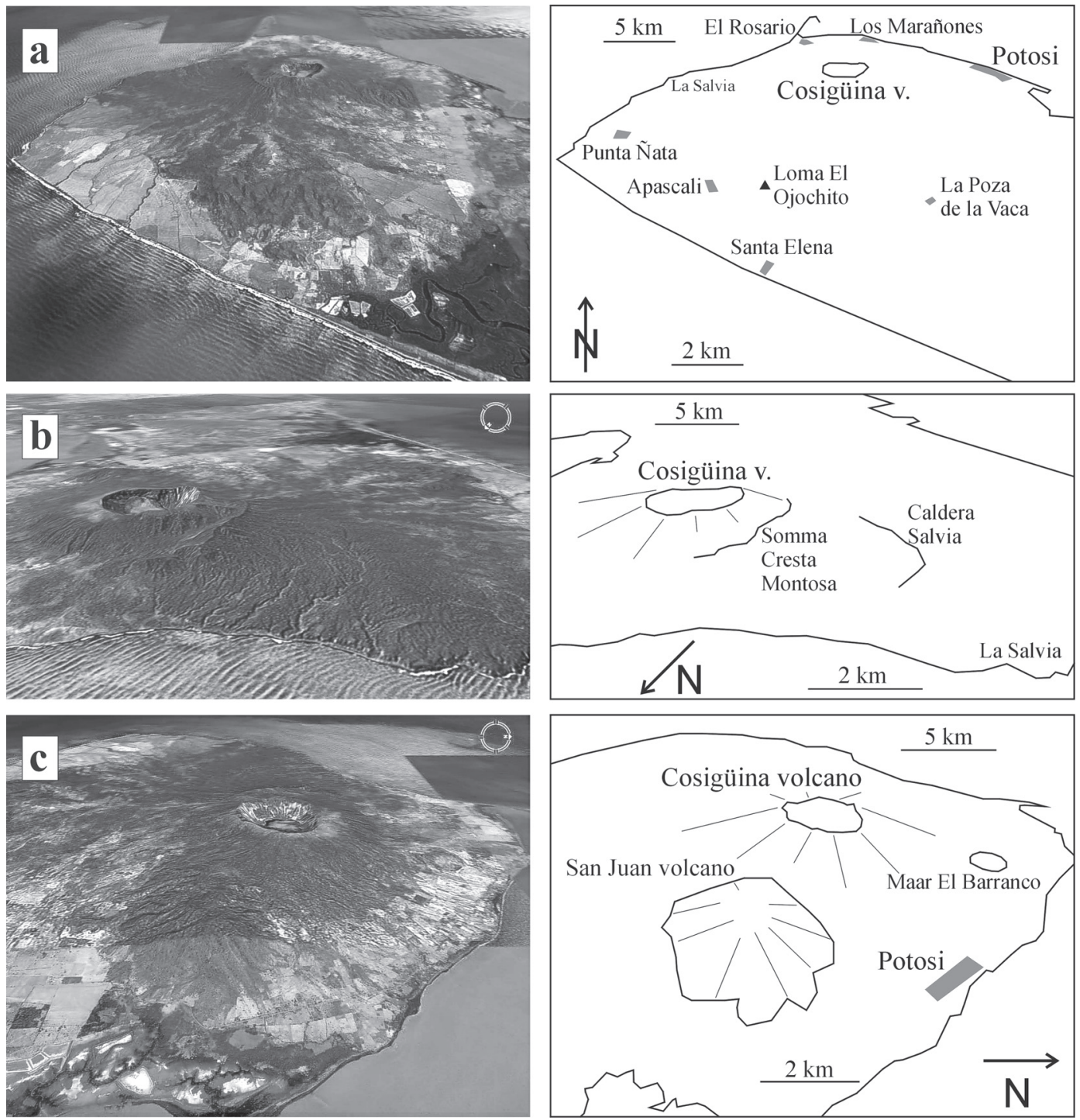

Fig. 2: Satellite images of the Cosigüina Volcano (source: www.earth.google.com) seen from a) south; b) northwest; c) east. Locations mentioned in text are marked. Images are in perspective, therefore scale-bars for front and rear are given.

shown in the photogeological map of "Catastro e Inventario de Recursos Naturales" (1972). Martínez \& Viramonte (1982) made a revision of the existing data on the volcano, but did not present any new data. Hradecký (1988) described the cliff section Punta Nata (now inaccessible) where the lowermost layers contained numerous buried animal bones, unfortunately not studied by any biologist or palaeontologist, and therefore not assigned to animal species.

General data were published in several summarizing works, e.g. by Williams (1972) and Weyl (1980), but lacking any detail description.

Self et al. (1989) summarized all available data from sections of the youngest deposits, stated that the 1835 famous eruption had 
commenced with phreatic activity, continued as a plinian eruption and finished as phreatic again. The analyzed rocks correspond to andesites. Scott et al. (2006) comprehensively studied the youngest - 1835 A.D. - eruption with paying only minor attention on previous activities. This author-team supposed, those eruption closely preceding eruption were of smaller magnitude then the famous 1835 A.D. one. They also reported some deposits of highmagnitude volcanic eruption, which is supposed to be at least few thousands years old.

Modern geological mapping (Fig. 3) accompanied with a new volcano-stratigraphic scheme (Fig. 4) have been compiled based on three weeks of field research held by the Czech geological expedition in 2001 (Hradecký et al., 2001).

\section{Methodology}

This paper summarizes the results of field and analytical research carried out by the team of Czech geologists - mainly from the Czech
Geological Survey. Over 60 outcrops were documented comprising 18 key profiles documented in detail (namely localities along "farallones" or cliffs on the northwest limits of the Cosiguiina peninsula). Individual defined volcaniclastic layers were correlated on the basis of volcanologic, lithologic and "overall-shape" characteristics (Fig. 5). The 1835 deposits were unfruitful for correlations, as this eruption buried all previous sequences over an erosional unconformity and therefore offer the only information that all other deposits are older. On the other hand, deposits of "dramatic surges" - DS were easily recognizable and their position in the middle part of the entire succession was really helpful especially on the western side of the volcano. For the elaboration of the map, the products of 1835 eruption were omitted from locations, where these are thinner than 0.5 $\mathrm{m}$. Otherwise, the map would appear unisonous and consisting solely of the 1835 tuffs, without such remedy. Nevertheless the 1835 tephra is ever present in low thickness all around the peninsula.

Twenty representative rock samples, of which sixteen belong to the proper Cosigüina Volcano, were

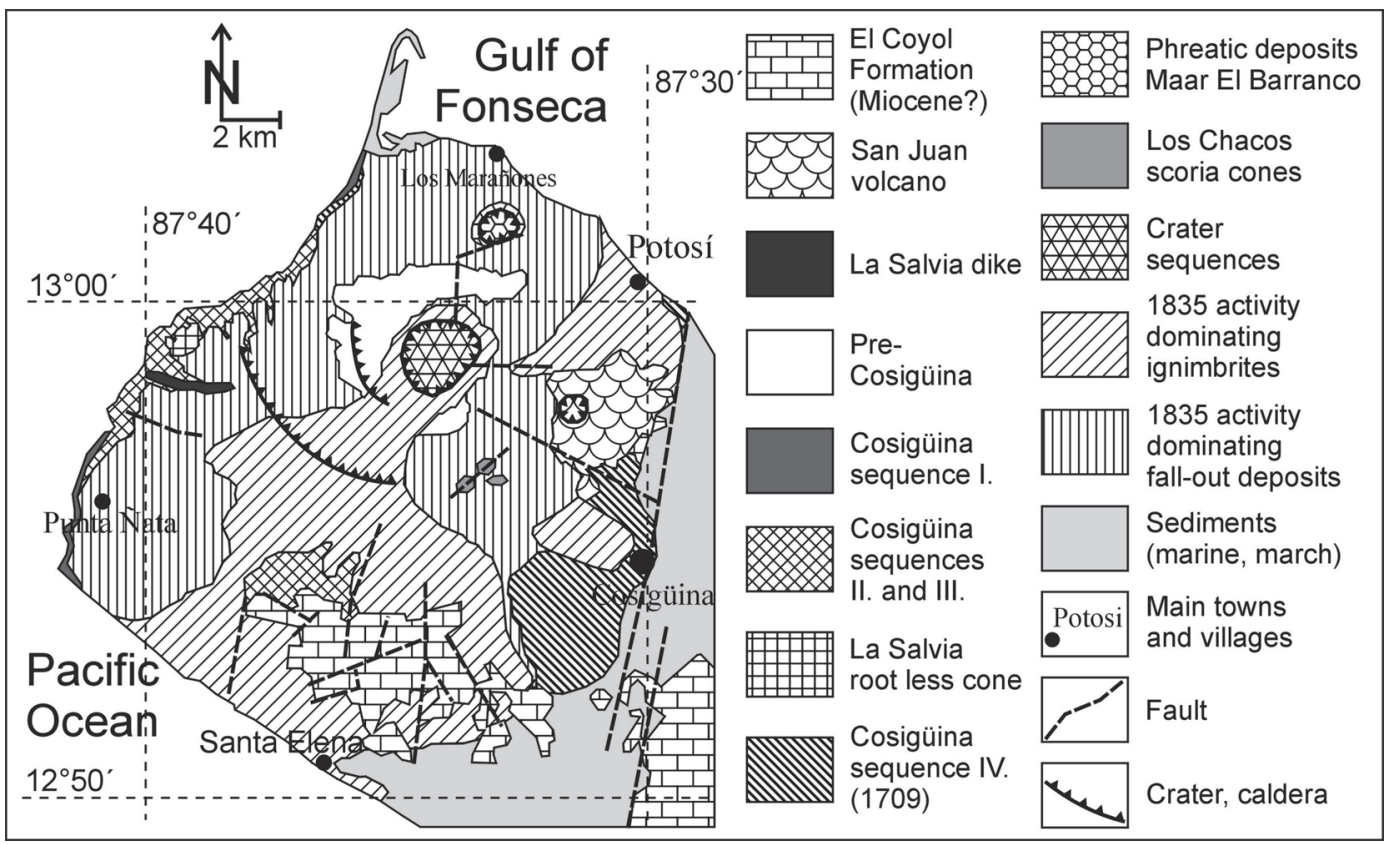

Fig. 3: Generalized geological map of the Cosigüina Volcano (simplified after Hradecký et al., 2001). 


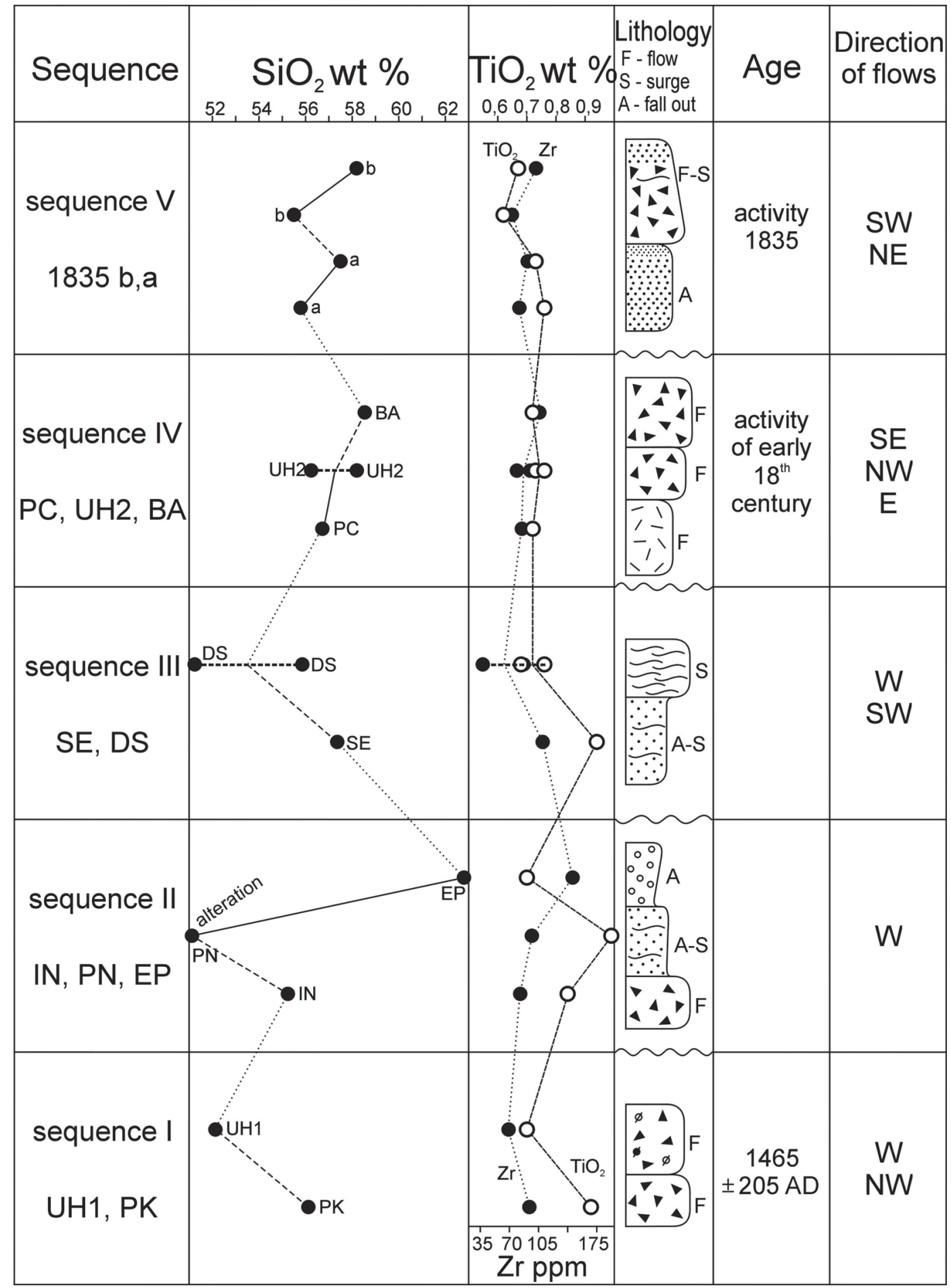

Fig. 4: Stratigraphic scheme of the explosive history of the Cosigüina Volcano. Stratigraphic and radiometric data accompany the main geochemical characteristics of the pyroclastic sequences. 


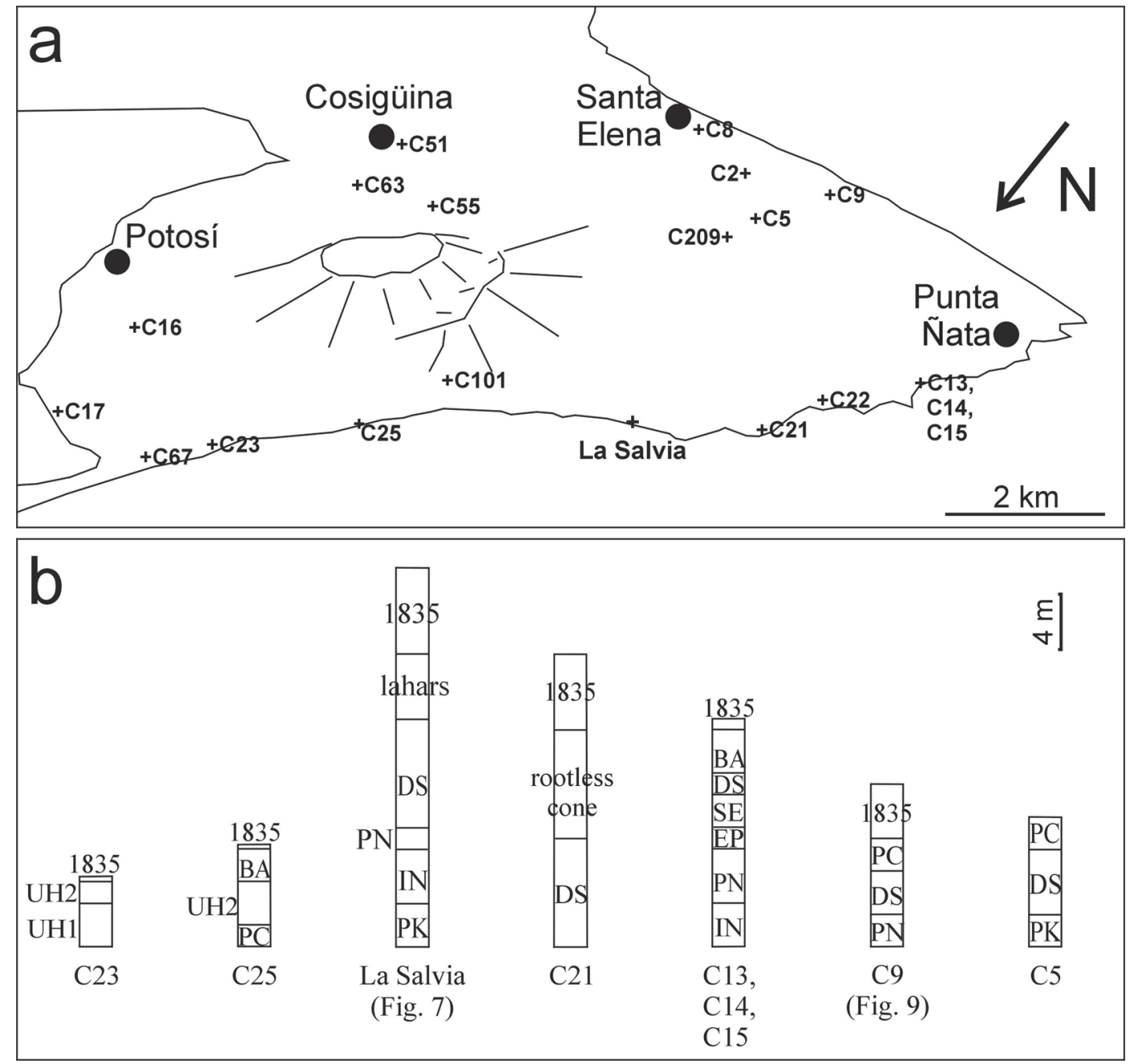

Fig. 5: a) Location of sampling- and detailed documentation sites (view from the NW). b) Correlation of main pyroclastic layers around the Cosigüina Peninsula.

analyzed in labs of the Czech Geological Survey in Prague. Silicate analyses were supplemented with selected trace elements determined using FAAS and XRF techniques. Analytical data were recalculated to water-free phase and plotted into diagrams in the GCDkit software (Janoušek et al., 2006). The common classification diagram of Le Bas et al. (1986), recommended by IUGS, was combined with the diagram of Winchester \& Floyd (1977) due to effortless remobilization of alkalis in pyroclastic material.

\section{VOLCANIC EVOLUTION OF THE COSIGÜINA VOLCANO}

\section{Pre-historic evolution of the Cosigïina peninsula}

The basement of the Cosigüina peninsula mostly consists of deeply weathered welded ignimbrites and lavas of the Coyol Formation. The basement is well exposed in the range of Loma El Ojochito (Figs. 2 and 3) and its occurrence continues to the 
mainland to the SE. A small block of the Coyol Formation also crops out at the foothill of the San Juan volcano (Fig. 3).

Two volcanic edifices representing Pleistocene volcanic activity cover the basement of the peninsula. These two eroded volcanoes occupy the major part of the peninsula, where the modern Cosigüina shield only represents the youngest stage of the volcanic system evolution.

San Juan volcano occupies the SE slopes of the Cosigüina Volcano, south of Potosí. Hradecký (1988) and van Wyk de Vries (1993) used the alternative name "Pleistocene volcano" for this apparatus. The stratovolcanic sequence is well shown in the northern side of the edifice, where non-welded, diagenetically indurated pyroclastic flow deposits contain abundant andesitic lithics. These deposits rest on the weathered lavas of the Coyol Formation in the southern part. Post-volcanic collapses deposited unsorted coarse debris flow accumulations, as is seen in a new road cut south of Potosí. The central part of the moderately eroded volcano consists of lavas with intercalations of proximal scoriae. San Juan volcano can be interpreted as an old shield volcano, probably of the same age as Pre-Cosigüina.

The term "Pre-Cosigüina" has been applied for lavas and associated pyroclastics that formed the original volcano, now preserved in the form of the relict of somma Cresta Montosa (Williams, 1952), better seen in the crater wall sections. Most of the area of the morphological somma is covered by dense vegetation and together with the older collapse structure of La Salvia, is blanketed by young tuffs. The structure can be identified by using aerial photographs. Pre-Cosigüina is considered as a relict of a probably Pleistocene shield volcano, which preceded the young cone.

La Salvia dyke lies inside layered deposits of pyroclastic flows at the Pacific coast of the peninsula. Although it reaches only some $1.5 \mathrm{~m}$ in thickness, this prominent dyke can be traced in distance of up to $3 \mathrm{~km}$. The dyke is probably of similar age as Pre-Cosigüina volcano and it was exposed by selective erosion. The apparent recent position of this dyke within the deposits of modern Cosigüina could be explained by filling of the relief around the exposed dyke by historical pyroclastic flows.

\section{Monogenetic forms of uncertain age}

Two monogenetic forms are located on the foothills of the Cosigüina Volcano. Maar Barranco (Fig. 3) is a small structure at the northeastern slope of the massif, built up by a phreatomagmatic eruption producing tephra rich in juvenile lithics - basaltic andesite in composition. Base-surge and fall-out deposits forming the tuff-ring are diagenetically consolidated and overhang the plain. The stratigraphic relations of this maar remain unclear. The degree of erosion could correspond to late Pre-Cosigüina stage.

Another volcanic feature rests on the southern slope of the volcano, probably associated with the final activity of Pre-Cosigüina and San Juan volcanoes. Los Chacos scoria cones (Fig. 3) were originated by small-scale Strombolian to Hawaiian eruption set on a NE trending rupture. These cones reveal the most primitive magma composition of all volcanic centers in the peninsula.

\section{Pyroclastic sequences of modern Cosigüina Volcano}

The later activity is more explosive in character, while lavas are more abundant in previous stages of the volcano evolution, and missing in last volcanic events. The subrecent and recent activity of the Cosigüina Volcano could be subdivided into five explosive phases:

Sequence I: pyroclastic flows PK, UH 1.

Sequence II: pyroclastic flows IN, scoria and pumice falls EP, pyroclastic surges PN.

Sequence III: pyroclastic surges DS, scoria falls SE.

Sequence IV: pyroclastic flows PC, UH 2 and BA.

Sequence V: pyroclastic flows, surges and ash fall, activity of 1835 . 
The explosive activity of these eruptive events was phreatic, phreatomagmatic and moderate plinian. The 1835 eruption seems to be relatively of small-scale in comparison with those preceding, judging from the thickness and distribution of the youngest tuffs. All defined sequences are separated one to other by erosional unconformities.

\section{Sequence I}

Prominent deposits of poorly welded pyroclastic flows can be traced along the northwest coast of the Cosigüina peninsula close to El Rosario. Thickness reaches up to $5 \mathrm{~m}$ without known bottom. These $\mathrm{UH}$ 1 deposits consist of basaltic lithics enclosed in an ash-matrix and often arranged in units tracing velocity gradients in a laminar flow (Fig. 6a). Greyishpink color is characteristic for these deposits and allows recognizing and correlating them. A typical feature is the abundance of carbonized tree-trunks (Fig. 6b) up to several meters long. Degassing pipes are abundant and concentrated above tree-trunks. Broken animal bones reported by Hradecký (1988) found at the bottom together with trees, can be taken as an evidence for a sudden volcanic blast, which destroyed forests and wildlife.

Radiometric data of charcoals from this deposit yielded approximately 500 B.P., suggesting eruption around the beginning of 16th century. Original $14 \mathrm{C}$ data from the deposits UH 1 (Sequence I) were calibrated by OxCal software (Ramsey, 2003; Table 1.).

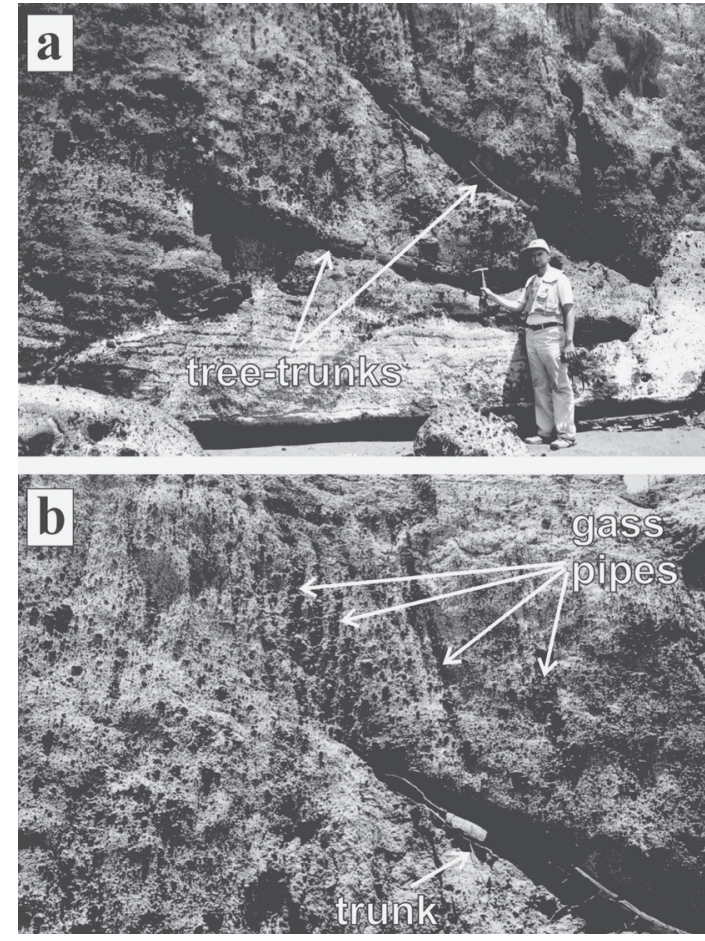

Fig. 6: a) Deposits of UH 1 pyroclastic flows of Sequence I. b) Carbonized tree-trunks up to $2 \mathrm{~m}$ long in deposits of UH 1 pyroclastic flows. Degassing pipes concentrate above trunks.

Thick deposits of PK pyroclastic flows crop out west of Ojo de Agua village (northwest of Punta Nata). Poorly welded and solidified deposits up to $12 \mathrm{~m}$ thick are overlain by DS surges. The matrix

Table 1

Calibration results of Sequence I radiocarbon data

\begin{tabular}{|c|c|c|c|c|}
\hline Non-calibrated data & $\begin{array}{c}\text { Probability } \\
64.1 \%\end{array}$ & $\begin{array}{c}1 \mathrm{~s} \\
4.1 \%\end{array}$ & $2 \mathrm{~s}$ & Calibrated ages \\
\hline \multirow[t]{2}{*}{$\begin{array}{l}498 \pm 127 \mathrm{BP} \\
\text { (PK) }\end{array}$} & 1300AD-1520AD & 1590AD-1620AD & 1260AD-1670AD & $1465 \pm 205 \mathrm{AD}$ \\
\hline & $65.0 \%$ & $3.2 \%$ & & \\
\hline \multirow[t]{2}{*}{$\begin{array}{c}505 \pm 127 \mathrm{BP} \\
\text { (UH 1) }\end{array}$} & $1290 \mathrm{AD}-1520 \mathrm{AD}$ & 1600AD-1620AD & 1260AD-1670AD & $1465 \pm 205 \mathrm{AD}$ \\
\hline & $65.1 \%$ & $3.1 \%$ & & \\
\hline $\begin{array}{c}506 \pm 127 \mathrm{BP} \\
(\mathrm{UH} 1)\end{array}$ & 1290AD-1520AD & 1600AD-1620AD & 1260AD-1670AD & $1465 \pm 205 \mathrm{AD}$ \\
\hline
\end{tabular}


corresponds to a basaltic andesite. Carbonized wood provided material for $14 \mathrm{C}$ data, which yielded close to UH 1 charcoals (Table 1), therefore this unit has been included, together with UH 1, to the Sequence I as the oldest exposed pyroclastic deposits of the modern volcano.

\section{Sequence II}

This sequence comprises mostly plinian deposits, which have been documented in the Tigüilitada, Punta El Papayal and La Salvia sections in coastal cliffs (northwest coast between Punta Nata and La Salvia). The block-and-ash pyroclastic flow and surge deposits (IN) are exposed in La Salvia, being $5 \mathrm{~m}$ thick (Fig. 7). The overlying phreatomagmatic unit PN consists of andesitic scoria and surge deposits in Tigüilitada section (between La Salvia and El Carmen) whereas in Apascalí, the profile is represented by air fall and mudflows.

The uppermost unit of Sequence II consists of light-grey pumice and repeated mingled magma-clast layers (EP, Fig. 8). Pumice corresponds to dacite as most silicic product of all Cosigüina analyzed rocks (Table 2).

\section{Sequence III}

Scoria falls on the SE can be best documented in the Tigüilitada section (between La Salvia and El Carmen, Fig. 8). Andesitic scoria reaches up to $3 \mathrm{~m}$ thick and was produced by moderate phreatomagmatic activity. The ages of Sequences II and III should be estimated on the basis of superposition as anytime between early 16th and early 17th century. Therefore, deposits of these two sequences could be assigned to the eruption in 1609 , which is commonly referenced as uncertain (Global Volcanism Program). The associated, $10 \mathrm{~m}$-thick surge and flow deposits DS (Figs. 9 and 10), of basaltic or andesitic composition, increase in thickness towards the NE. This well-preserved and distinctive unit can be traced in all documented sections - Tigüilitada, Apascalí and La Salvia.

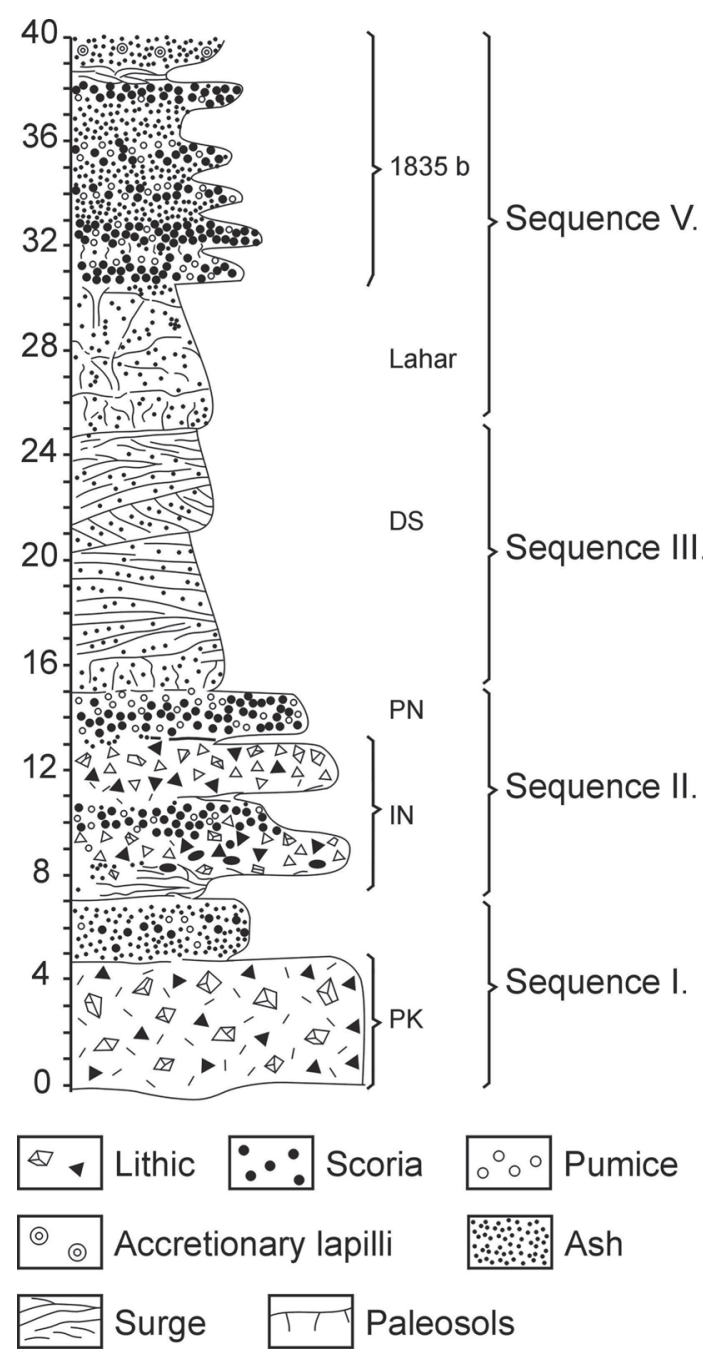

Fig. 7: Pyroclastic succession in the area of La Salvia, where sequence IV does not crop out. Abbreviations correspond to the names of pyroclastic units used in the text..

\section{Sequence IV}

There is an erosional unconformity between deposits of DS and Sequence IV (weathered surface). PC pyroclastic flows initiated the activity of this sequence. Deposits of PC are discontinuous and widespread covered UH2 pyroclastic flows (Fig. 11). The latter ones are represented by coarse-grained, non-welded, but well-cemented pyroclastic 


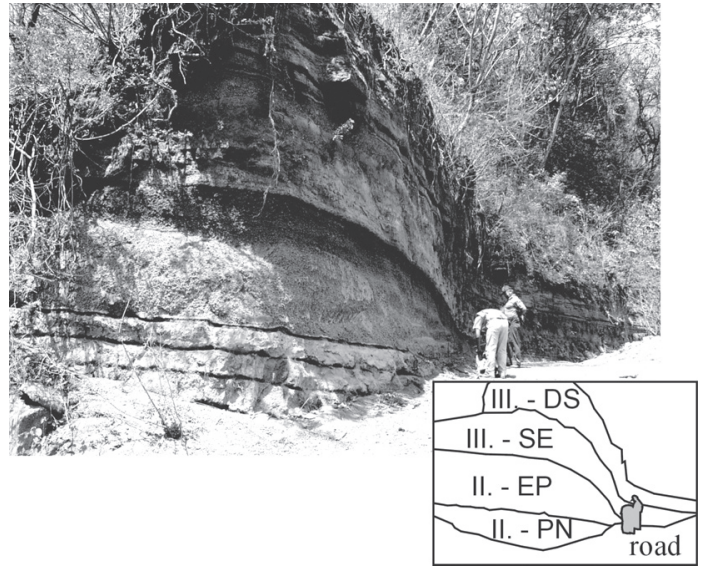

Fig. 8: Section at Tigüilitada. Silicic pumice of EP (in the middle) grades continuously to the darker scoria (magma zoning). Scoriae SE (Sequence III) overlie a paleosol of EP. Deposits of "dramatic surges" DS (Sequence III) are well exposed in the upper part of this section.

flow deposits occasionally containing fragments of carbonized wood. Calibration of radiocarbon data from the Sequence IV eruption were not possible. On the other hand, reviews on historic reports (Incer, 1983, 1988; Global Volcanism Program) present the possible eruption in 1709. This date well fits to our radiometric data (Table 1; Fig. 5).

The last unit BA forms parts of the coastal cliffs close to La Salvia. Some equivalents of the sequence were found also in the eastern side of the peninsula (San Marcos and Aguas Calientes, south of Potosí). All deposits are block-and-ash flows and scarce co-ignimbritic fallout tuffs.

\section{Sequence V (1835 AD)}

This sequence corresponds to the well-known eruption in 1835. A lot of good exposures have been documented, such as in Santa Elena, Apascalí, Tigüilitada, La Salvia, etc. The maximum thickness is about $8 \mathrm{~m}$. The lower part (1835a) is composed of scoria fall (probably a plinian blast), whereas scoriaceous pyroclastic flows of andesitic composition dominate the upper part (1835b).

The uppermost part of the sequence is represented by fine co-ignimbrite ashes of a typical yellowish color, that reach up to $2 \mathrm{~m}$ between
Punta Nata and Apascalí. On the other hand, irregular mudflows form the base of the deposit. Wide and short degassing pipes perpendicular to the surface of mudflow served as conduits for lukewarm water steam. Coarse-grained and poorly sorted lag-fall breccias surround the crater, showing good welding.

The activity of 1852 and 1859 , reported by Incer $(1983,1988)$ and the Global Volcanism

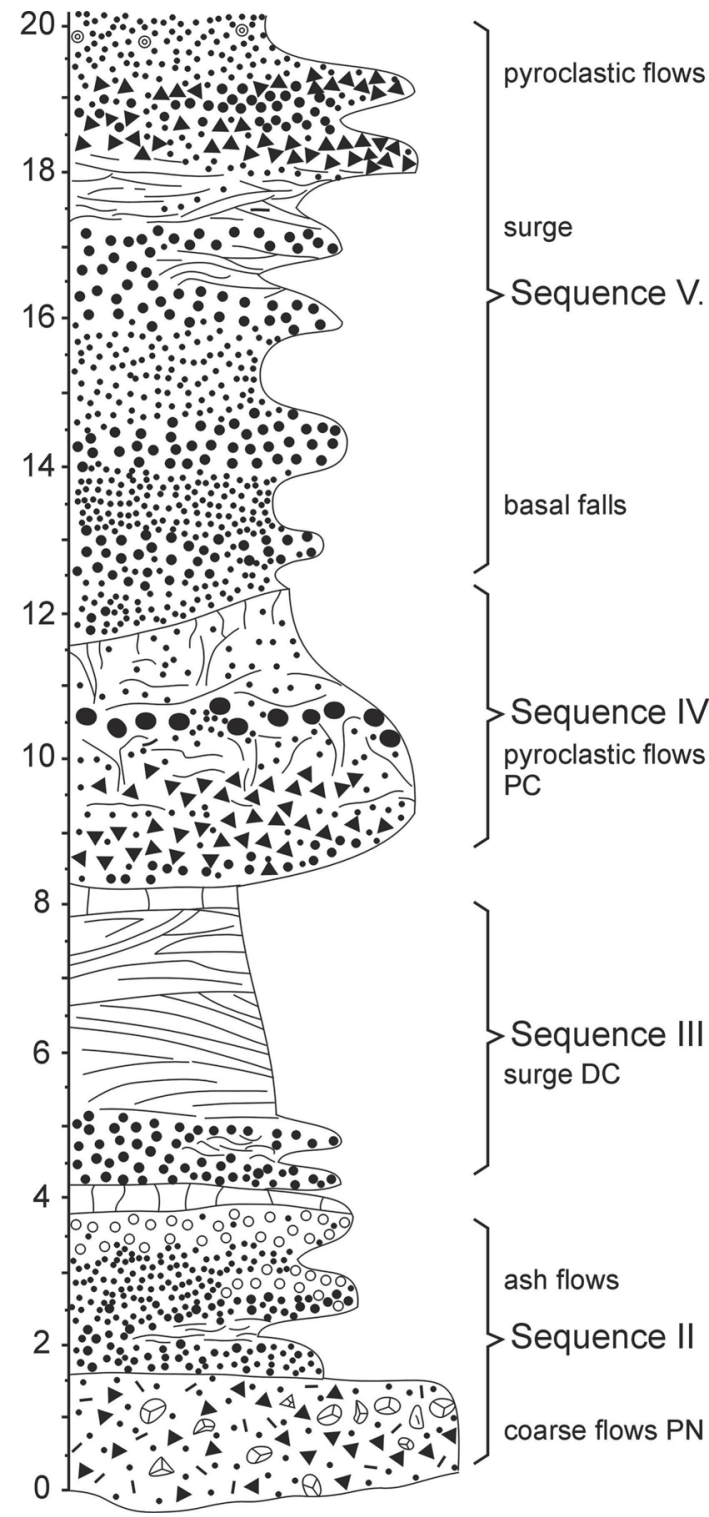

Fig. 9: Pyroclastic succession in the area of Apascalí. 


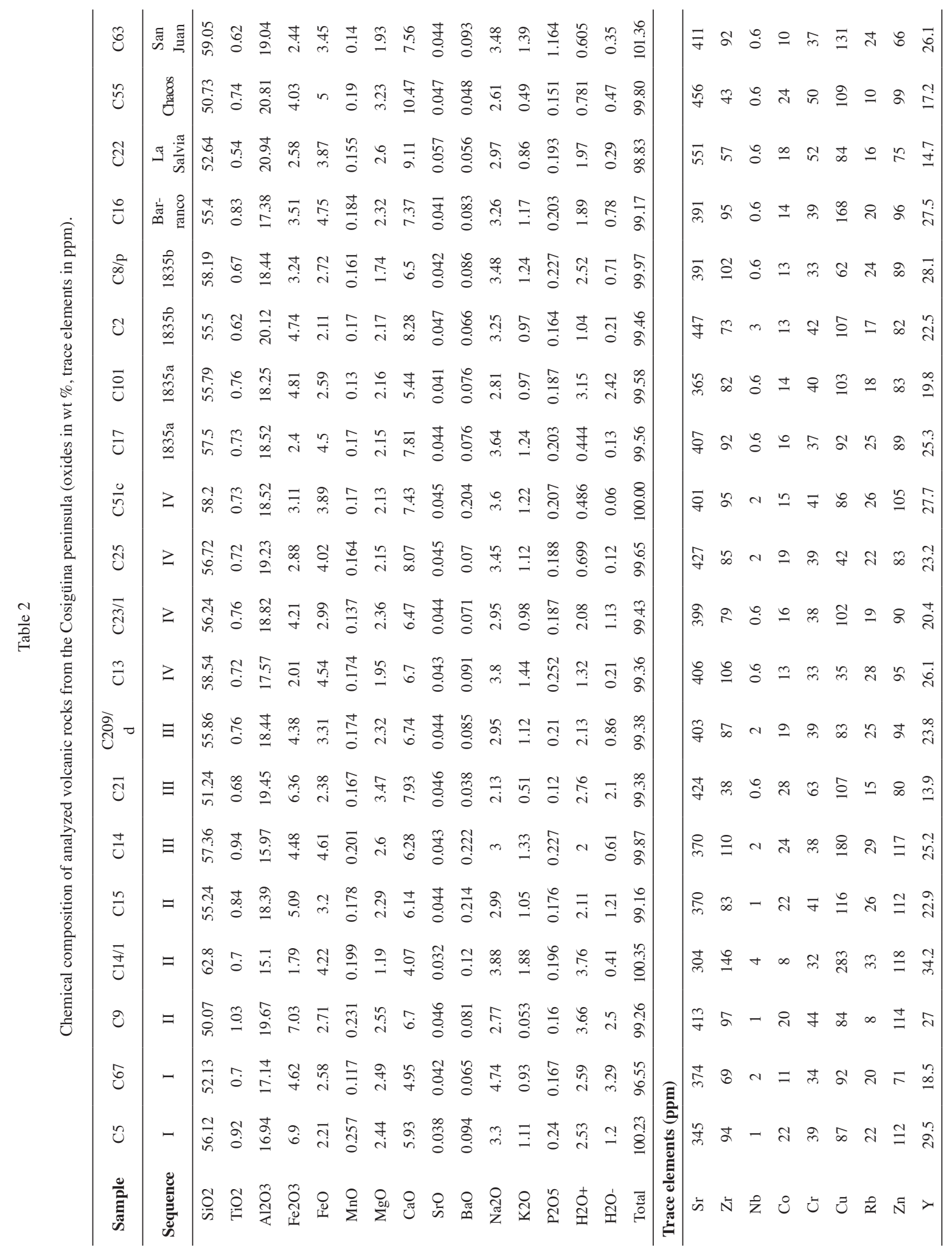


Program, most probably correspond to minor ash eruptions not preserved till nowadays. Bushfires could also explain these poorly described events.

Only few small fumaroles in the crater-lake and thermal water springs at the eastern feet of the edifice represent the recent activity.

\section{COMPOSITION OF ERUPTED MAGMAS}

The erupted magmas of the Cosigüina Volcano are relatively monotonous in composition. Most of the analyzed samples from the eruptive sequences have basaltic andesitic to andesitic composition. The studied samples were classified using the IUGS recommended TAS diagram (Le Bas et al., 1986; Fig. 12a). Since the pyroclastic material is prone to hydration and other postmagmatic alterations affecting predominantly the alkali contents, the classification was further confirmed in the diagram of Winchester \& Floyd (1977; Fig. 12b). No big differences in the resulting classification were revealed, denoting low alteration or low

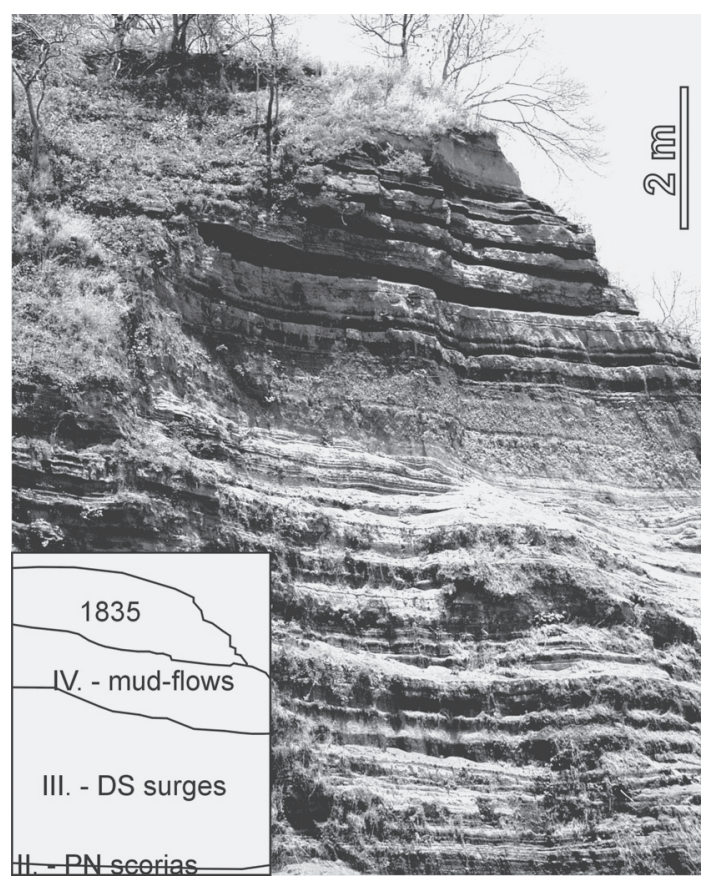

Fig. 10: Section east of La Salvia with complete succession of pyroclastic products of Sequence V (1835 AD) on top.

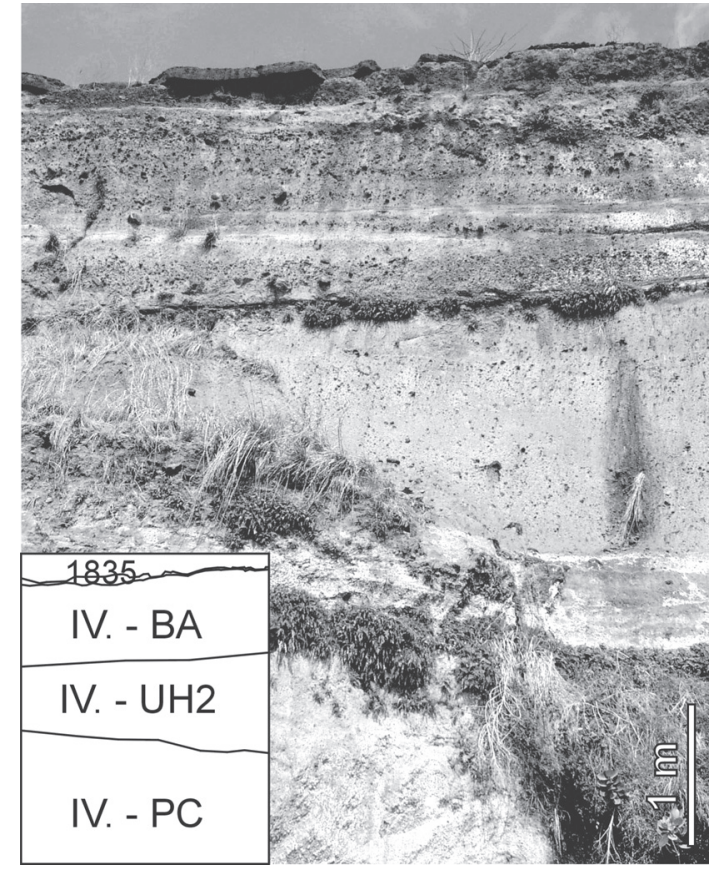

Fig. 11: Deposits of pyroclastic flows of Sequence IV on the NW coast of the peninsula. At the base, non-welded deposits of pyroclastic flows (PC), middle part consists of cemented pyroclastic flow deposits (UH2) and the sequence is crowned with block-and-ash BA deposits. Thin layer of 1835 eruption covers the deposits of Sequence IV.

depletion in mobile elements, including samples relatively rich in water. The only exception is the sample C67 slightly enriched in Na due to impregnation of porous pyroclastic material with seawater salts (outcrops are in the reach of tides).

Mid-K and calc-alkaline character of volcanic material produced from the Cosigüina Volcano corresponds to an active continental margin (Figs. $12 \mathrm{c}$ and 12d). The observed trends are in good agreement with data from other volcanoes of the Nicaraguan front (database of Carr et al., 2003), although in some cases the scatter of the present data is more pronounced than in the whole reference dataset. Although the data for some main oxides are scattered and the trends are not clear, a general decrease in compatible element contents such as $\mathrm{Mg}, \mathrm{Ca}, \mathrm{Fe}, \mathrm{Ti}, \mathrm{Al}$ as well as $\mathrm{Sr}$ and $\mathrm{Cr}$ may be observed, accompanied by the increase in incompatible element contents, such as $\mathrm{K}, \mathrm{Na}$, 


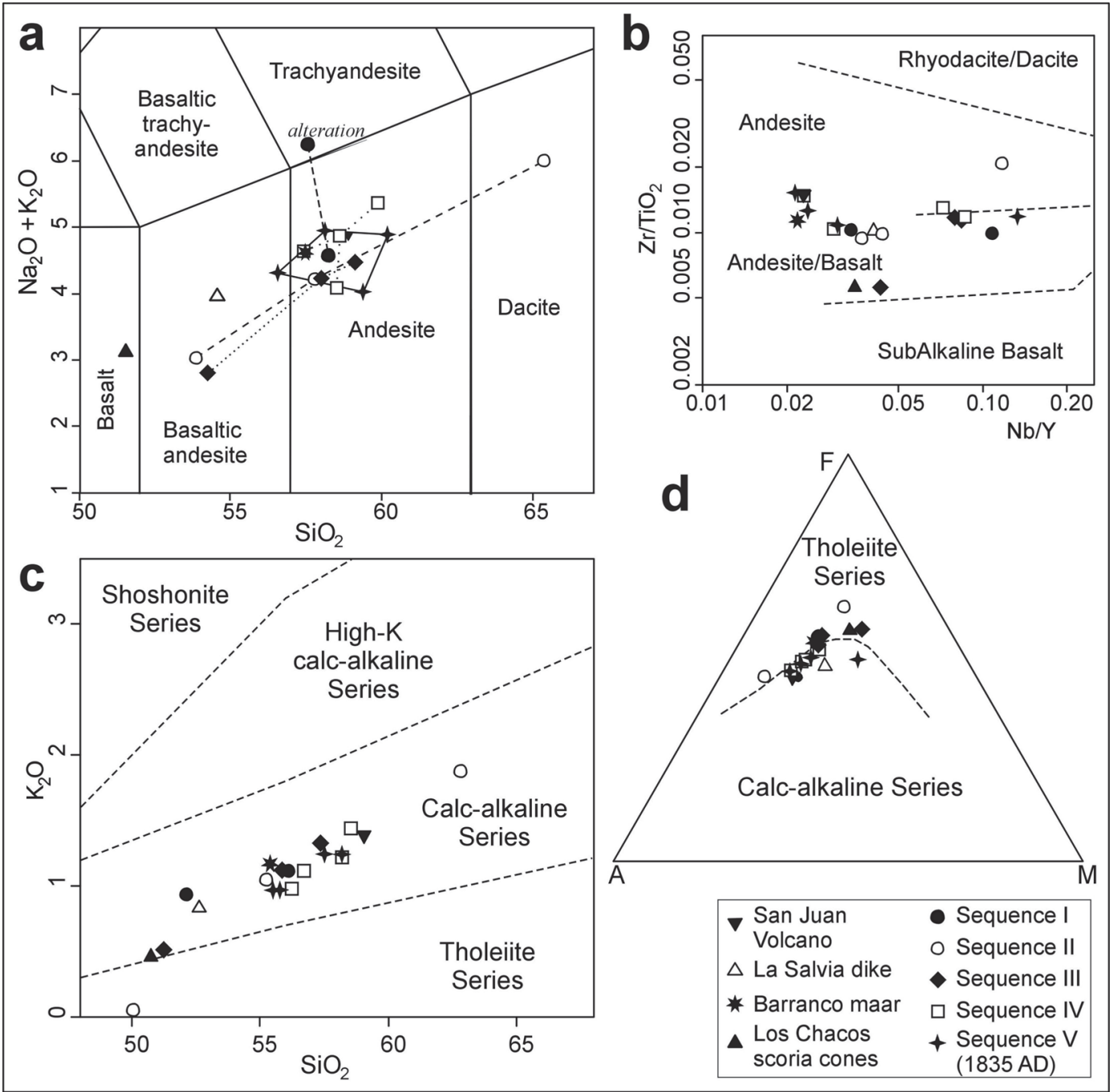

Fig. 12: a) TAS diagram (Le Bas et al., 1986) with rocks of the Cosigüina Peninsula; b) Nb/Y - Zr/TiO2 diagram (Winchester \& Floyd, 1977) based on immobile elements, more applicable to hydrated pyroclastic material; c) SiO2-K2O diagram (Peccerillo \& Taylor, 1976); d) AFM diagram (Irvine \& Baragar, 1971) of the Cosigüina volcanic rocks showing the calc-alkaline character overlapping the field of tholeiitic rocks.

$\mathrm{Rb}, \mathrm{Zr}$ and $\mathrm{Y}$. Such trends may be attributed to a common fractional crystallization of anorthitic plagioclase, iron rich olivine and/or clinopyroxene and Ti-magnetite. However, the detailed compositional trends within individual suites are far from linearity. Only the Sequence II shows a more significantly zoned reservoir together with an almost linear compositional trend for all main oxides. The span between the most primitive sample and the most evolved one, corresponds to ca $30 \%$ of fractional crystallization. This activity had finished with dacitic pumiceous fallout deposits of the EP unit (sample C14/1).

A singular sample demonstrates the andesitic composition of the Pleistocene San Juan shield volcano. As this study has not been focused on this extinct volcano, only one sample of this volcano has been analyzed. 
The variation in composition of the Pleistocene rocks is similar to the recent Cosigüina, ranging from basaltic andesites to andesites, except for the very primitive Cerros los Chacos scoria cones. The andesitic composition of the juvenile scoria of the El Barranco maar (sample C16 in the Table 2) is very similar to the composition of most of the pyroclastic material erupted from the Cosigüina Volcano. The dike of La Salvia is more basic (basaltic andesite), but also yields into the composition range of Cosigüina products.

Scoriae of the Cerros Los Chacos cinder cones are more mafic (basaltic). These should represent some more primitive magma, which probably never reached the main magma chamber. Their position on the SW-NE trending faults suggests a relation to the Guayape fault system, which probably enabled a rapid ascent of the melt.

\section{DISCUSSION AND CONCLUSIONS}

After a Pleistocene volcanic activity forming Pre-Cosigüina and San Juan shield volcanoes, a period of more explosive events took place. Five large eruptions are characteristic for the evolution of the Cosigüina volcano within the last 500 years. Phreatic, phreatomagmatic and moderate plinian eruptive styles characterized these last volcanic events of modern Cosigüina. Phreatic influence strongly increased the explosivity of andesitic (and scarcely dacitic) magma. The last eruption in 1835 was not the most violent one. Phreatic eruptions of high explosive energy took place when seawater infiltrated along fault zones (probably related to the Guayape fault system) to the magma reservoir. Such process could cause another violent phreatic or phreatomagmatic eruption in the future. Pyroclastic flows and fallout would endanger villages and the seaport of Potosí on the Cosiguiina peninsula.

\section{ACKNOWLEDGMENTS}

We gratefully acknowledge the Czech Ministry of Foreign Affairs and the Ministry of Environment of the Czech Republic for the financial support of the study within the framework of "Development assis- tance projects". Authors would like to give thanks to all field co-workers (in alphabetical order): Havlíček P., Hrubeš M., Mrázová Š., Opletal M., Šebesta J. and Ševčík J., as well as to laboratory analysts of the Czech Geological Survey and to Dr. Melková from Charles University (Prague) for 14C datings. The field campaign in Nicaragua was logistically supported by INETER, W. Strauch and E. Mayorga from the Department of Geophysics and Geology of this institution. Thanks to the anonymous reviewer.

\section{REFERENCES}

BURKART, B. \& SELF, S., 1985: Extension and rotation of crustal blocks in northern Central America and effect on the volcanic arc.- Geology, 13: 22-26.

CATASTRO e INVENTARIO de RECURSOS NATURALES, 1972: Geologic map. Sheet ND 16-14; Plate IV-3D; Chinandega, Nicaragua; Honduras.

FINCH,R.C.\& RITCHIE,A.W., 1991: The Guayape fault system, Honduras, Central America.- J. South Amer. Earth Sci. 4(1-2): 43-60.

\section{GLOBAL VOLCANISM PROGRAM -} SMITHSONIAN National Museum of Natural History: Cosigüina.- URL: http:// www.volcano.si.edu/world/volcano. cfm?vnum=1404-01=

HRADECKÝ, P., 1988: Los aspectos geológicos de la 1835 erupción del Volcán Cosigüina, Nicaragua. 38 págs.- Archive INETER, Managua [unpublished report].

HRADECKÝ, P., HAVLÍČEK, P., MAYORGA, E., OPLETAL, M., RAPPRICH, V., ŠEBESTA, J. \& ŠEVČÍK, J., 2001: Geological study: Research on natural hazards and vulnerability of geological environment in the region of the Cosiguiina volcano. (in Czech and Spanish). 36 págs.- Archives INETER Managua and CGS, Prague [unpublished report]. 
INCER, J., 1983: Crónicas sobre la gran erupción del Cosigüina.- La Prensa, 23th January 1983, Managua.

INCER, J., 1988: Central American volcanic events (1524-1924).- 52 págs. [unpublished manuscript].

IRVINE, T.N. \& BARAGAR, W.R.A., 1971: A guide to the chemical classification of the common volcanic rocks.- Can. J. Earth. Sci. 8: 523-548.

JANOUŠEK, V., FARROW, C. \& ERBAN, V., 2006: Interpretation of whole-rock geochemical data in igneous geochemistry: introducing Geochemical Data Toolkit (GCDkit).- J. Petrol. 47(6): 1255-1259.

Le BAS, M.J., Le MAITRE, R.W., STRECKEISEN, A. \& ZANETTIN, B., 1986: A chemical classification of volcanic rocks based on the total alkali-silica diagram.- J. Petrol. 27: 745-750.

MANN, P. - ed., 1995: Geologic and Tectonic Development of the Caribbean Plate Boundary in Southern Central America.349 págs. Geol. Soc. Am. Spec. Paper 295.

MARTÍNEZ, J. \& VIRAMONTE, L., 1982: Geologia y riesgos volcánicos de Nicaragua.- 67 págs. Archive INETER, Managua [unpublished report].

McBIRNEY, A. \& WILLIAMS, H., 1965: Volcanic history of Nicaragua.- Univ. California Press 55: 1-65.

PECCERILLO, R. \& TAYLOR, S.R., 1976: Geochemistry of Eocene calc-alkaline volcanic rocks from the Kastamonu area, Northern Turkey.- Contrib. Mineral. Petrol. 58: 63-81.
RAMSEY, C.B., 2003: OxCal Program v 3.9 - University of Oxford - Radiocarbon Accelerator Unit.- URL: http://www.rlaha. ox.ac.uk/oxcal/oxcal.htm

SCOTT, W., GARDNER, C., DEVOLI, G. \& ALVAREZ, A., 2006: The A.D. 1835 eruption of Volcán Cosigüina, Nicaragua: A guide for assessing local volcanic hazards.Geol. Soc. Am. Spec. Pap. 412: 167-188.

SELF, S., RAMPINO, R. \& CARR, M.J., 1989: A reappraisal of the 1835 eruption of Cosigüina and its atmospheric impact. Bull. Volcanol. 52: 57-65.

STUIVER, M., REIMER, P.J. \& BRAZIUNAS, T.F., 1998: High-precision radiocarbon age calibration for terrestrial and marine samples.- Radiocarbon 40(3): 1127-1151.

Van WYK De VRIES, B., 1993: Tectonics and magma evolution of Nicaraguan volcanic system.- 328 págs. Dept. of Earth Sciences, Open University, Milton Keynes [PhD. thesis].

WEYL, R., 1980: Geology of Central America. 371 págs. Gebrüder Borntraeger, Berlin.

WILLIAMS, H., 1952: The great eruption of Coseguina, Nicaragua in 1835. - Univ. Calif. Pub. Geol. Sci. 29: 21-45.

WILLIAMS, R.L. - ed., 1972: The geology of western Nicaragua. - 221 págs. Parsons Corp. Final Technical Report [unpublished report].

WINCHESTER, J.A. \& FLOYD, P.A., 1977: Geochemical discrimination of different magma series and their differentiation products using immobile elements. Chem. Geol. 20: 325-343. 